\begin{tabular}{|c|c|}
\hline & Volume \& Issues Obtainable at The Women University Multan \\
Annals of Social Sciences and Perspective \\
ISSN: 2707-7063, Volume 2, No.1 June 2021
\end{tabular}

\title{
Social and Marital Life of Disable Baggers: A Case Study of Multan
}

\section{Muhammad Hashim ${ }^{1}$, Dr. Yasir Nawaz ${ }^{2}$, Syed Waqas Shabir ${ }^{3}$, Inam-ul-Haq ${ }^{4}$}

${ }^{1}$ Ph.D Sociology Scholar, District Health Communication and Support Officer.

${ }^{2}$ Associate Professor, Chairperson Department of Sociology and Criminology, University of Sargodha.

${ }^{3}$ Ph.D Scholar, Department of Sociology, University of Faisalabad, Pakistan

${ }^{4}$ Assistant Professor, Govt. Islamia College Kasur, Pakistan.

\begin{tabular}{ll}
\hline \multicolumn{2}{l}{ ARTICLE DETAILS } \\
\hline History: & \\
Received: $\quad$ June 02,2021 \\
Review: $\quad$ June 15,2021 \\
$\begin{array}{ll}\text { Accepted: } & \text { June } 15,2021 \\
\text { Available Online: June } 30,2021\end{array}$
\end{tabular}

\section{Keywords:}

Social and Marital Life, Population, Disable Baggers, Multan.

\begin{abstract}
Social and marital life of special people who are Bagger (case study of Multan city) Objective of the Study) this study was about socio-cultural, economic, legal, infrastructural and environmental factors that affect marital life of special people and the sociocultural factors in which sense affect the weeded life of handicap bagger Especially in Multan the special people are facing problems related to socio-marital life and problems regarding Bagger in Multan a simple alternative to bagging is to partition the data into separate subgroups. This study was descriptive and the nature of the research was qualitative ten case were examined with the help of interview guide and the data was analysis at the end of each case study. The purposive and convenient sampling was used as a data collection tool the target population was the Multan city and surrounding.
\end{abstract}

(C) 2021 The Authors, Published by WUM. This is an Open Access Article under the Creative Common Attribution Non Commercial 4.0

Corresponding authors email address: hashimsocial@yahoo.com

\section{Introduction}

The town of Multan, one of Asia's oldest subcontinent cities, which is regarded the "Santa Zone," is located in Central Pakistan about $562 \mathrm{~km}$ from the capital, Islamabad. Hindu legends mention Multan in the battle with the Hindu Epic, as the capital of Kingdom of Trigarto and the dynasty of Katoch. In 1947, Multan became a member of Pakistan and of the old buildings Multan dated to the 17th and 18th Century after the partition of the Indian Subcontinent. (Day 2012) (Day 2012) (Dawn 2012) (Dawn 2012) Starting with the parents who always took him/her to another place to get Islamic knowledge to be a village, city or city. In culture in particular, food and shelter are traumatic in their lives. Beggars can be seen as a group of people who rely on the livelihood of their lives. Any beggars are found at a younger age. Four of them are 10 years of age, and in some places you can find excavators in their own homes up to the age of five years. Under one (teacher) control, there are two to hundred beggars, and sometimes more than 100, the teacher cannot handle them 
appropriately as he is intended. Due to the dirty garments they wear and the place they sleep and feed, drinking is also a contaminated body of these bags which can easily provide for some diseases. (Extract from French).

\section{An Honor for a Special Person}

Islamabad, Jan 4: Dr Aamir Hanif Raja, who has completed his $\mathrm{PhD}$, is the first visually blind teacher in history. The Organization for Islamic Cooperation (OIC) and European Union are compared in its research paper (EU). Dr. Aamir, 39, was a member of Kirpa, a rural region of the federal capital and facing all the obstacles, completed his studies. (Dawn 2013) (Dawn 2013) He was chosen as an instructor in Asghar Mall College, RaWalpindi, and he now teaches as an adjunct lecturer. He also travelled to United Kingdom when talking to Dawn that he finished his PhD from Punjab Uni. He said. He said. "I earned a 2006 Higher Education Commission scholarship in merit and received PhD financing," he said. 'In Great Britain, blind people had plenty of services. I researched at a research centre specifically designed for visually disabled persons," he said. "I had to face a lot of critique when I began studying, but I kept on going and finished my doctorate. I conclude that people begin to give him value and reverence in our society when an individual shows himself to be. The same happens to me, I get appreciation from other people at least now," he said. "I have ensured each student at my college that I am his good friend and am teaching them in a nice atmosphere whereby my topic results are more than 90\%," (Dawn 2013) (Dawn 2013) We are currently working similarly, however, to compare bagging methods for easy division of massive datasets. In districts, Multan started a new counter-Beggary operation. Recently, TMA officers started to seize all male beggars and handed over tens of beggars to police officers. More than 200 beggars fought at the Faisalabad police station on Monday and hurled stones and bricks. In all districts we need an organised camp, and the police must be involved," said Sadiq official of TMA in Multan. TMA officials in Sialkot, Faisalabad, and Multan have already carried out a brief survey showing that most beggars are located on street crossings, on sites and in shopping areas in both districts. (Forum 2011) These citizens do not have institutions or detox centres, so they go back to the streets," said an official. Recently, over 300 professional beggars including women and excavators were joined by the Social Welfare Department of Faisalabad but were permitted to go to the markets a couple of days later. "This is because laws and bagger refurbishing facilities allow us to intervene but it is much tougher to do the same thing for adults," said Welfare Department official Rahmat Javed. "They have the power to give bagger to the Child Protection Office (CPB). In the efforts made at different phases of programme implementation, and most importantly, evaluating the severe and increasing disability and how individuals with disabilities can be included in development process, the seriousness of a community in the treatment of persons with disabilities reflects the efforts made.

\section{Procedure of the Study}

This research is qualitative in nature. The case studies were taken to collect data . The logics behind this was the less population of the disable married bagger. The universe of this study was the Multan city and surrounding areas.

\section{Significance of the Study}

The present study deals with the issues of Social and marital life of special: people who are Bagger in Multan. In Pakistan majority of the population living below the poverty line Special people as a bagger are there in Pakistan at risk for behind their limited access to basic 
facilities, such as health, education, and recreation. However, has found that the greater the exposure to stressful events, the greater the probability of deviant behavior when special people as a beggared are faced with later stresses.

\section{Limitations of the Study}

The present research has its own limitation in terms of resources, scope and time frame. . Following are the limitations for the present research.

- The study was limited to Multan city.

- Married beggars.

- Beggars are the area of disabilities i.e. mental retarded, physical handicap, and visual impaired were included in this study.

\section{Review of Relevant Literature}

Scientific analysis is not an independent hermits' operation that does not recognise other results. It is instead a collection of several researchers who share their findings and who seek expertise as a culture. While certain experiments may be particularly significant and individual studies may become renowned, a new study project is only a small part of the overall mechanism for building information on the basis of previous researchers' studies to compare replicates or critique them for weakness.

John, J. J. In colleges and universities there are no services in favour of higher education for special persons. (2003) The business is small. The requirements of vocational training programmes are not entirely satisfied for parents and special individuals. What makes people with disabilities wish to beg! (Groce: unpublished interview, 2010) The question of whether many individuals with handicaps decide to beg in this broader literature is lost. Where religious instructions thank people for their gift, begging may be less frowned upon and beggars are seen to contribute to the well-being of society. (Affairs and Austrian Development Agency, 2006) Women's empowerment was based on economic and financial empowerment but now its concept has been wider which involves Psychological, intra home relational, Socio cultural, legal and political aspects (Majoor, Manders and Femconsult, 2009). Empowerment of women is a mechanism that improves women's ability to make decisions about desired events and outcomes. (Hebrew, 2013). The mechanism to create and improve the capacity of individuals in economic, social and political aspects for structuring their own lives and their communities (Affairs and Austrian Development Agency, 2006). Gender equality The definition refers to the rights of all humans, such that all the wishes of men and women are given equal consideration.(MacMillan, 1850) claimed that a letter of supplication concerns a wealthy or organised individual, normally written by a poor person or by a person who claims to be poor, begging for money or assistance. The letter of supplication was a letter. In the novelist Charles Dickens' post, the begging-letter writer mentions descriptions of the many begging letters he had received over the years and the ruses used by their authors for the purpose of earning funds from the beneficiaries.

The disabilities in Pakistan are classified into physical disabilities, hearing deficiency and mental impairment (Akhtar, 2013). Disabilities of disability are classified as disabilities. In addition, these are graded as mild, moderate, and severe/deep. Since there are many known causes of disability, the precise causes of disability are unclear. Disability is likely due to the effects of different conditions. 


\section{Research Methodology}

Methodology: This research is qualitative by nature and the case studies was taken to collect that .The logics behind this was the less population of the disable married bagger. The universe of this study was the Multan city and surrounding areas.( the main logics behind this was the easily access to the Multan population and better understanding about the culture also customs of Multan especially the language and related information regarding their home and activities of the disable married beggars or their excitement with society.

Population of the study: The target population of this research thesis was the married disabled married baggers. Sample of the study: The sample size was ten cases from the Multan city three male and seven female so necessary changes were brought according the research ethics/ and methods.

Sampling Technique: Purposive and convenient sampling was used for sample selection. Purposive and convenient sampling was logically appropriate for this research. The purposive sampling was necessary to identify the bagger and is he/she was married or not because the study was the explanation of the disable person's marital problems and other they are associated with them.

Tool of the study: This present study of was the qualitative research involves the use of qualitative data, such as Case studies, In-depth interview with the help of interview guide. So the tool for data collection was interview guide and this is appropriate for this research because some disable married bagger were unable to read and write, so this was the suitable for this research.

Validations of the tool: Tool of this study was validated with the help of expert's opinions.

Data collection: The data was collected from the Multan city and surrounding from the mentally disable, visual impair, and other disable persons they were involved in bagging and were disable.

Data Analysis: The critical analysis of each case was written by the researcher. The data analysis was used to analyze the data for the present research (case studies). The cause studies were critically analyzed by using the critical descriptive analysis.

\section{Data Analysis}

The data analysis and the tables were interpreted with the respect of all data results and the all data was explaining about the positions of different responses. The critical analysis was written at the end of every case study.

\section{Case Study No.1}

\section{Demographic Data:}

$\begin{array}{ll}\text { Name } & \text { Kalsoom Bibi } \\ \text { Age } & 18 \text { Year } \\ \text { Order of Birth } & 1 \mathrm{st} \\ \text { Marital Status } & \text { Married }\end{array}$




$\begin{array}{ll}\text { Education } & \text { Illiterate } \\ \text { Profession } & \text { Bagger } \\ \text { Family Type } & \text { Nuclear Family } \\ \text { Caste } & \text { Rajpoot } \\ \text { Family Income } & 3100-4000 \\ \text { Mental illness } & \text { Disoriented psychiatric patient } \\ \text { Causes } & \text { Mental disability } \\ \text { City/Village } & \text { Multan }\end{array}$

\section{Family Background:}

Respondents belong to a lower class family of Khan Multan Kalsoom Bibi was an illiterate woman. She has two brothers and two sisters. Her family monthly income was 3100-4000. Her husband occupation was laborer.

Detail of Case: Respondent name was Kalsoom Bibi. Her age was 18 years. She was a married. Her caste was Rajpoot. She was living near the Multan basically she was belong to village but due to baggers she was living in city area close by BZU. She was a patient of Psychiatric disoriented i.e. Depression. The behavior of her in laws was nonassertive. They torture her in different forms and she cries.

Analysis of the case: Researcher observes during interview that respondent was in tension, depression. And this was the cause of her as baggers. The behavior of society was hating. She has not children due to the ill health and disability.

\section{Case Study No.2}

\section{Demographic Data:}

$\begin{array}{ll}\text { Name } & \text { Maqsooda Banu } \\ \text { Age } & \text { 35 Year } \\ \text { Order of Birth } & \text { 2nd } \\ \text { Marital Status } & \text { Married } \\ \text { Education } & \text { Primary } \\ \text { Profession } & \text { baggers } \\ \text { Family Type } & \text { Nuclear Family } \\ \text { Caste } & \text { Sheikh Ansari } \\ \text { Family Income } & 4100-5000 \\ \text { Mental illness } & \text { Anxiety, Depression } \\ \text { Causes } & \text { Mental disability (Mood dis order) } \\ \text { City/Village } & \text { Multan }\end{array}$

Family Background: Respondents belong to a lower class family of Multan. Her education level was primary. She has three brothers and two sisters. Her family monthly income was ranging 4100-5000. Her husband occupation was laborer.

Detail of Case: Respondent name was Maqsooda Banu. Her age was 35 years. She was a married. Her caste was Sheikh Ansari. She lives in urban areas of Multan. She was a patient of Anxiety and Depression and mood disorder. Her husband beats him daily and burns her hand due to this she was facing mood disorder. In depression she cries, gets out from home and has odd behaviors even with friends and family. At last her husband got out from home and she was worried about children. 
Analysis of the case: In this case researcher analyses that the behavior of her husband was very cruel with her. The idea of having a home encompasses living in a place that afford physical and psychological safety and security, then a woman experiencing violence in her home was in a very real sense, homeless.

\section{Case Study No.3}

\section{Demographic Data:}

$\begin{array}{ll}\text { Name } & \text { Tabasum Fatima } \\ \text { Age } & \text { 26 years } \\ \text { Order of Birth } & 1 \text { st } \\ \text { Marital Status } & \text { Unmarried } \\ \text { Education } & \text { Secondary } \\ \text { Profession } & \text { Household Woman (baggers) } \\ \text { Family Type } & \text { Joint Family } \\ \text { Caste } & \text { Julahay } \\ \text { Family Income } & 4100-5000 \\ \text { Mental illness } & \text { Anxiety, Depression and psycho problems } \\ \text { Causes } & \text { Mental dis ability and (gender bender) } \\ \text { City/Village } & \text { Multan }\end{array}$

Family Background: Respondents belong to a lower class family of Multan. Her education level was secondary. She has two brothers and five sisters. Her family monthly income was ranging 4100-5000.

\section{Detail of Case:}

Respondent name was Tabsum Fatima. Her age was 26 years. She was a married. Her caste was Julahay. She lives in rural areas of Multan. She was a patient of Anxiety, Depression and Anger. The main cause of her mental illness was daily bases quarrels and family issues regarding the marriages and watasata She fights with her members of family without any reason break the juge, glass even she was facing Mental dis ability and her husband was also handicap they have 2 children their age was less than 5 year they was school going children and one children that name was Fatima she was disable and another children that name was Zafar he was normal and have 3 year old Her parents engaged her through the watasata and now a days she was road bagger her bagging time was full day because the expense of her family was more and the income was very low she tells us the Govt. of Punjab cannot made a sustainable strategy to overcome the problems of

\section{Analysis of the case:}

Researcher observes during interview that respondent was in anxiety and depression due to disability but she was happy because her children will one day be capable to solved her all problems and she was interested the education of her children .

\section{Case Study No.4}

\section{Demographic Data:}

$\begin{array}{ll}\text { Name } & \text { Asghar } \\ \text { Age } & 32 \text { years } \\ \text { Order of Birth } & 7 \text { th }\end{array}$




$\begin{array}{ll}\text { Marital Status } & \text { Married } \\ \text { Education } & \text { Middle } \\ \text { Profession } & \text { Bagger } \\ \text { Family Type } & \text { Nuclear Family } \\ \text { Caste } & \text { Sheikh Abbasi } \\ \text { Family Income } & 7000-8000 \\ \text { Disability } & \text { Handicaps and economic problem } \\ \text { Causes } & \text { By accident } \\ \text { City/Village } & \text { Multan }\end{array}$

Family Background: Respondents belong to a Middle class family of Multan. Her education level was Middle. He has four brothers and four sisters. His family monthly income was ranging 7000-8000.

Detail of Case: Respondent name was Asghar. His age was 32 years. He was a married. His caste was Sheikh Abbasi. He lives in urban areas of Multan. He was a patient of T.B, Irregular and handicap during the accident he has lost his one leg now a day's passing his life time with the support of his bagged rupees. The main cause of her mental illness was being a handicap and disable other family member beat him and set him at road for the purpose of bagging he cannot use that rupees even for his clothing or children education and careers and family welfare or his medicine.

Analysis of the case: Researcher observes during interview that respondent was in anxiety and depression due to behavior of husband and her in laws.

\section{Case Study No.5}

\section{Demographic Data:}

$\begin{array}{ll}\text { Name } & \text { Qasim } \\ \text { Age } & 27 \text { years } \\ \text { Order of Birth } & 1 \text { st } \\ \text { Marital Status } & \text { Married } \\ \text { Education } & \text { Primary } \\ \text { Profession } & \text { Household Woman } \\ \text { Family Type } & \text { Joint Family } \\ \text { Cast } & \text { Syed } \\ \text { Family Income } & 5100-6000 \\ \text { Mental illness } & \text { Depression } \\ \text { Causes } & \text { Death of father (Deaf) } \\ \text { City/Village } & \text { Multan }\end{array}$

Family Background: Respondents belong to a lower class family of Multan. His education level was Primary. He has three brothers and three sisters. His family monthly income was ranging 5100-6000. Detail of Case: Respondent name was Qasim. His age was 27 years. He was a married and caste was Sayed. She lives in urban areas of Multan. She was a patient of Anxiety and Depression.

Analysis of the case: Researcher observes during interview that respondent was in anxiety and depression due to his father death and nonassertive behavior of wife. Respondent was in emotional deprivation and suffer from distress psyche problems. 


\section{Case Study No.6}

Demographic Data:

$\begin{array}{ll}\text { Name } & \text { Allah Ditta } \\ \text { Age } & \text { 40 years } \\ \text { Order of Birth } & \text { 2nd } \\ \text { Marital Status } & \text { Married } \\ \text { Education } & \text { Illiterate } \\ \text { Profession } & \text { bagger } \\ \text { Family Type } & \text { Nuclear Family } \\ \text { Cast } & \text { Bhatti } \\ \text { Family Income } & 4100-5000 \\ \text { Mental illness } & \text { Depression, Anger } \\ \text { Causes } & \text { Burden of daughters and dowry (low family income) } \\ \text { City/Village } & \text { Multan }\end{array}$

Family Background: Respondents belong to a lower class family of Multan. He was an illiterate. She has two brothers and four sisters. His family monthly income was ranging 4100-5000.

Detail of Case: Respondent name was Allah Ditta. His age was 40 years. He was married. His caste was Bhatti. He thinks about the future of her three daughters all over the times.

Analysis of the case: Researcher observes that respondent was in anxiety and depression due poverty because He has three daughters. The main problem of respondent were the financial issue. He feels the burden of dowry and how could he manage the dowry of three daughters

\section{Case Study No.7}

\section{Demographic Data:}

$\begin{array}{ll}\text { Name } & \text { Shameem } \\ \text { Age } & \text { 35 years } \\ \text { Order of Birth } & 7 \text { th } \\ \text { Marital Status } & \text { Married } \\ \text { Education } & \text { Primary } \\ \text { Profession } & \text { Household Woman } \\ \text { Family Type } & \text { Nuclear Family } \\ \text { Cast } & \text { Bhatti } \\ \text { Family Income } & 5100-6000 \\ \text { Mental illness } & \text { Anxiety, Depression and Anger (by profession bagger) } \\ \text { Causes } & \text { Husband behavior } \\ \text { City/Village } & \text { Multan }\end{array}$

Family Background: Respondents belong to a lower class family of Multan. Her educational level was primary. She has four brothers and three sisters. She was a household woman and bagger. Her family monthly income was ranging 5100-6000.

Detail of Case: Respondent name was Shameem. Her age was 40 years. She was married. Her caste was Bhatti. She was bagger by profession; her mother was also a bagger and she socialized her to be a good bagger. 
Analysis of the case: Researcher observes during interview that respondent was feeling depression Respondent was in tension and cries for her children because children was small she was want to send him/her for education in nearby school. Her husband prohibited him to send children. Her husband was want to make money and don't want to send his children to school.

\section{Case Study No.8}

\section{Demographic Data:}

$\begin{array}{ll}\text { Name } & \text { Raees bibi } \\ \text { Age } & 25 \text { years } \\ \text { Order of Birth } & 1 \text { st } \\ \text { Marital Status } & \text { Married } \\ \text { Education } & \text { Primary } \\ \text { Profession } & \text { Bagger (special person and old age) } \\ \text { Family Type } & \text { Joint Family } \\ \text { Caste } & \text { Arain } \\ \text { Family Income } & 4100-5000 \\ \text { City/Village } & \text { Multan }\end{array}$

Family Background: Respondents belong to a lower class family of Multan. Her education level was Primary. She has two brothers and five sisters. She was a household woman. Her family monthly income was more than 5000 thousand.

Detail of Case: Respondent name was Raees. Her age was 25 years. She was a married. Her caste was Arain. She lives in rural areas of Multan She was a patient of Anxiety and Depression. She was now a days a old lady and she was bagger she also trained her daughter for bagging and tackle the family related issues.

Analysis of the case: Researcher observes that the family of Raees was illiterate and the cause of her mental illness that formulating bad behavior. Respondent in laws preference the birth of son but Raees has no son; belong to poor family and bagging was his profession to earn money for basic need.

\section{Case Study No.9}

Demographic Data:

$\begin{array}{ll}\text { Name } & \text { Najma Khan } \\ \text { Age } & \text { 26 years } \\ \text { Order of Birth } & \text { 2nd } \\ \text { Marital Status } & \text { Married } \\ \text { Education } & \text { Secondary } \\ \text { Profession } & \text { Bagging } \\ \text { Family Type } & \text { Joint Family } \\ \text { Cast } & \text { Bhatti } \\ \text { Family Income } & 4100-5000 \\ \text { Mental illness } & \text { Anxiety, Depression and Anger and dumb } \\ \text { Causes } & \text { by birth (dumb) } \\ \text { City/Village } & \text { Multan }\end{array}$


Family Background: Respondents belong to a lower class family of Multan. Her education level was secondary. She has two brothers and 2 sisters. She was a household woman. Her family monthly income was ranging 4100-5000.

Detail of Case: Respondent name was Najma Khan. Her age was 26 years. She was a married and facing Anxiety, Depression Anger and dumb. Her caste was Bhatti. She lives in city areas of Multan. She was a patient of Anxiety, Anxiety, Depression and Anger and dumb. The main cause of her bagging was Anxiety, Depression, and Anger and dumb because of a huge burden of poverty Anxiety, Depression and Anger and dumb she feels deprivation and fights with her members of family without any reason.

Analysis of the case: Researcher observes during interview that respondent has have maximum money and belong to good family. Socio-economic factors were responsible of patient; mental illness and bagging.

\section{Case Study No.10}

\section{Demographic Data:}

$\begin{array}{ll}\text { Name } & \text { Humaira Bahar } \\ \text { Age } & 14 \text { years } \\ \text { Order of Birth } & 4 \text { th } \\ \text { Marital Status } & \text { Married } \\ \text { Education } & \text { Illiterate } \\ \text { Profession } & \text { Bagger } \\ \text { Family Type } & \text { Joint Family } \\ \text { Cast } & \text { Muslim shekh } \\ \text { Family Income } & 6100-7000 \\ \text { Causes } & \text { Anxiety, Depression and Anger and dumb/deaf. } \\ \text { City/Village } & \text { Multan }\end{array}$

Family Background: Respondents belong to a Middle class family of Multan. Her education level was Illiterate. She has four brothers and three sisters. Her family monthly income was ranging 6100-7000.

Detail of Case: Respondent name was Humaira Bahar. Her age was 14 years. She was a married. Her caste was Muslim sheikh.

Analysis of the case: Researcher observes during interview that respondent was in anxiety and depression due to early child marriage and marital adjustment, anxiety, depression, anger and dumb her husband tortures her and depress.

\section{Summery Finding Conclusion \& Suggestions}

\section{Summary}

Disable women's bagger knowledge is specific, unlike difficulties to enjoying rights because of gender discrimination. We must redefine each recognized human right, (women's rights) and profile 'new' human privileges from the viewpoint of disable women's needs. In Islamic point of view, equality between the genders is the prevalent theme in the Quran Pak. Pakistan is also Islamic country but it is still facing the problem of disable oppression especially the women's due to male governing society and the violation on the base of disability, poverty. 
Lack of awareness, child marriages rape and forced beggary .This study has been conducted in the field of special education, an important and modern science to explain the social life of women's and male particularly the special person's in this research unfolding the social problems and disparities facing by the disable and violation of disable rights, and the participation in the field of development.

The main objectives of the study were.

1. To determine causes of begging with disability.

2. To determine remedial services for disable bagger.

3. To assess the problems of the bagger with disability.

This study was conducted in in the domain of qualitative research 10 case studies was conducted. Also was unpacked that in what ways the social and customary laws adversely affect the women's civil rights as a social being. In the other hand this research was explaining anti-women's rights and anti-women's custom's that are prevalent in Multan an interview guide (case studies) was used as a tool for data collection and researcher personally conduct in-dept. interviewed from the respondents. This study also suggested that there is need to remove the all types of violence against the women's and government must should implement all laws to protect the women's like strongly implement the act, property act, and women's protection bill and anti -customary laws, solved related problems of women's like the Poverty, educate for all.

\section{Finding}

1) All the bagger was compelled by the family due to reach his/ her disability.

2) The married special bagger children's were facing problems regarding to their future / education.

3) The family members set him / her on the bank of roads for the purpose of bagging because they are disabling and cannot afford the family life so the parents of Special girls were found worry about the future of their children.

4) Most of the bagger has had their residence place but they are living on road along with were in trouble due to financial and physical disparities.

5) The disable people were bagger because they don't have any other fields to do work and develop their social life.

6) All special persons were willing about their children education but they want to socialize them as a bagger because there were not found any other alternative.

7) The families of disable women's were facing problem's according to marital life and adjustment in society.

8) The disable bagger feels this is our right to beg because we don't have any other source of income.

\section{Conclusion}

The disable persons are facing problems regarding their financial position's, children's future, marital social life, health, force bagging and the limited information about his /her rights so the family and other members set him or her at roads for bagging some family forcibly compel him/ her for bagging. The BISP programe is also fail because they don't have CNIC for this need a separate policy at uc level to generate funding for such bagger's and work for behavior change communication, government empower them through skill and education. 


\section{References}

Acar, h. 1996. Sokak Çocuklarına Yönelik Hizmetlerin Degerlendirilmesi: Sosyal Hizmetlerve Çocuk Esirgeme Kurumu Örnegi. (Yayınlanmamıs DoktoraTezi), Ankara.

Assies, Willem. 1993. to Get Out of the Mud: Neighborhood Associativism in Recife, 19641988. Amsterdam: Centrum voor Studieen Documentatie van Latijins.

ATAUZ,S.,1996. Diyarbakır Sokak Çocukları Arastırması. Uluslararası Lions Md- 1180 Yönetim Çevresi: Diyarbakır.

Affairs, F. M., \& Austrian Development Agency, G. a. (2006). Gender Equality and Empowerment of women; Policy Document.

Bhudh-sko in 1860, use talks about street performances and begging https: // en .Wikipedia. Org / wiki / street performance.

Belisaire Regret in his study 1767 https: // en .Wikipedia. Org / wiki / Belisarius Chaudhry Sanam Akhtarb.S (Hones) 7th Semester Iscs $\mathrm{Pu}$ Lahore http://www.pkhope.com/disabled-population-in-pakistan/

Dagona, h. Z. (2012, 12 4). Desert herald. Retrieved from http://desertherald.com/beggarslife-in-the-society-almajiranci/

Dawn.Com 19th March 2012 write the history of Multan as a saint http /// www. Dawn .com/ news/ 703845 / Multan- the- city-of- saints.

D.T. Jones. Protein secondary structure prediction based on decision-specific scoring matrices. Journal of Molecular biology, 292:195-202, 1999.

Dictionary of Macmillan from Wikipedia, the free encyclopedia For Charitable Donations and Begging Letters from Nigerian 419 Fraud Scammers on the Crimes of Persuasion website https: // en .Wikipedia. Org / wiki / Begging- letter.

Dawn newspaper published a report Published Jan 04, 2013 09:20pm an honor for a special person .http: // www. Dawn. Com / news / 776299 / an honor - for -a- specialperson-2.

E. Bauer and R. Kohavi. An empirical comparison of voting classification algorithms: Bagging, boosting and variants. Machine Learning, 36(1, 2), 1999.

Express newspaper reported this in 2011http://tribune.com.pk/story/208408/begging-for-asolution-crackdown-against-beggary-proves-counterproductivel Published in The Express Tribune, July $13^{\text {th }}$, 2011.

Freyre, gilberto. 1968 [19361b. Sobrados e mocambos: decadencia do patriarcado rural e desenvolvimentourbano. Rio de janeiro: joseolympio.

F.J. Provost, D. Jensen, and T. Oates. Efficient progressive sampling. In Proceedings of the Fifth ACM SIGKDD International Conference on Knowledge Discovery and Data Mining, pages 23-32, 1999.

F.J Provost and D.N Hennessy. Scaling up: Distribtuted machine learning with cooperation. In Proceedings of the Thirteenth National Conference on Artificial Intelligence, AAAI '96, pages 74-79, 1996.

Fizza Haroon Lahore in February 10, 2011 by http:// www. Pakistan today. Com.pk /2011/02/10/ comment/ editors - mail/ street - begging/

Geddes, B.J. (1997) Childhood and Children: A Compendium of Customs, Superstitions, Theories, Profiles and Facts. The Oryx press. Arizona.

Glauser, Benno. 1990. "Street Children: Deconstructing a Construct." In Constructing and Reconstructing Childhood: Contemporary Issues in the Sociological Study of Childhood, edited by Allison James and Allan Prout, 138-156. London: Falmer Press.

Groce, N. 2010. Interview with disabled beggars. Field notes: Interview 3, Agra, India. Feb. 2010. Unpublished. 
IVES, R. "Volatile Substance Abuse: A Review of Findings in ESPAD 2003, Drugs: education, prevention and policy, Oct., 2006; 13(5): 441-449.

ILO International labor organization that https://en.wikipedia.org/wiki/Trafficking_of_bagger\#Child_begging

J. R. Quinlan. Bagging, boosting, and C4.5. In Proceedings of the Thirteenth National Conference on Artificial Intelligence, pages 725-730, 1996.

Jesus explain in 1181 about the religious orders that are linked with church https: // en .Wikipedia. Org / wiki /mendicant -orders

June explain in 2002 about the begging the wikipedia, the free encyclopedia in June 2002 https: // en .Wikipedia. Org / wiki internet begg-ing.

Khatoon, A. (2003). A historical and evaluative study of special education in Pakistan (Doctoral dissertation, University of Karachi.

Krishna, A. (2003). Social capital, Community Driven Development and Empowerment: A short note on concepts and Operations. World Bank working paper 33077.

L.O. Hall, K.W. Bowyer, W.P. Kegelmeyer, T.E. Moore, and C. Chao. Distributed learning on very large data sets. In ACM SIGKDD Workshop on Distributed and Parallel Knowledge Discovery, 2000.

L. Breiman. Pasting bites together for prediction in large data sets. Machine Learning, 36(1, 2):85-103, 1999.

L. Breiman. Bagging predictors. Machine Learning, 24(2):123-140, 1996.

Lewin, Linda. 1987. Politics and Parentela in Paraiba: A Case Study of Family- Based Oligarchy in Brazil. Princeton: Princeton University Press.

Nasaw, David. 1985. Children of the City: At Work and at Play. Garden City, N.Y.: Anchor/Doubleday.

Nitesh Chawla, Thomas E. etl USA Department of Computer Science and Engineering University of Notre Dame, Notre Dame, Indiana baggingIs a small-data-set phenomenon. P.O. Box 969, MS 9951, Livermore, CA, 94551-0969 Chawla,wpk@ca.sandia.gov. O'Connor, Denis. 1992. Glue Sniffing and Volatile Substance Abuse. Aldershot, UK: Gower.

P. Domingo's. Why does bagging work? A Bayesian account and its implications. In Proceedings of the Third International Conference on Knowledge Discovery and Data Mining, 1997.

P. Chan and S. Stolfo. Learning arbiter and combiner trees from partitioned data for scaling machine learning. In Proc. Intl. Conf. on Knowledge Discovery and Data Mining, pages 39-44, 1995.

P. Chan and S. Stolfo. Scaling learning by meta-learning over disjoint and partially replicated data. In 9th Florida Artificial Intelligence Research Symposium, pages 151-155, 1996.

P. Chan and S. Stolfo. Towards parallel and distributed learning by meta-learning. In Working Notes AAAI Workshop on Knowledge Discocery in Databases, pages 227240, 1993.

Rubin, Herber J., and Irene S. Rubin. 1994. Qualitative Interviewing: The Art of Hearing Data. Thousand Oaks, Calif.: Sage.

St Lawrence JS, Brasfield TL.HIV risk behavior among homeless adults. AIDS Educ Prev. $1995 \mathrm{Feb} ; 7(1): 22-31$.

Stephens, Sharon. 1997. "Editorial Introduction: Children and Nationalism." Childhood 4 (1): 5-17.

TedlaDiressie. (1996): Research Papers on the Situation of Children and Adolescent in Ethiopia. In 'Children in Especially Difficult Circumstances in Ethiopia', Addis Ababa. 
Thorne, Barrie. 1993. Gender Play: Girls and Boys in School. Buckingham: Open University Press.

Wikipedia the free encyclopedia May 2004 was written about the fundraising https://en.Wikipedia.Org/wiki/fundraising

\section{Appendix 1}

Non-governmental organizations

(NGOs)

End Child Prostitution in Asian Tourism

(ECPAT)

Organization of Islamic Cooperation

(OIC)

European Union

United Kingdom

Child Protection Bureau

The National Council for Rehabilitation of Disabled Persons

(NCRDP)

National Trust for Disabled

(NTD)

\section{Interview Guide}

Dear Respondants

I am a Ph.D scholar conducting a research on Social and marital life of special people who are Bagger (case study of Multan city) it's helpful for academia and NGO's to established policy and support the for bcc and encourage the community for fund raising and give respect and inclusion into to social development.

You are requested to provide your responses independently. The information will be kept confidently and will not be used for any other purpose.

Thank you,

Ph.D scholar UOS/

Health Communication and

Support Officer

\section{Demographics (Part-I)}

Q: 1: Name:

Q: 2: Education:

Q: 3: Gender:

Q: 4: Marital Status

Q: 5: Occupation

Q: 6: How much property do you have explain your life story?

Area/ problem

What about your life and family which types of the problems do you heve/face

Caste

Disability Cause

Marital Status

No. of Children

Oppression/Problem

Area of bagging

Before disability Occupation

Life story/personal life /marital life/ 
Q: 7: Are you aware of their basic rights

Q: 8: Are Ngo's working aimed at disable persons especially in educational / home/ food/

Q: 9: Do you feel it's your right to beg as a bagger

Q: 10. Is beggary of disable peoples under the influence of other baggers?

Q: 11 Do you feel Administration of District Multan neglecting the disable rights

Q: 12 Bagging is considered to be the profession /lively hood of male / female disable.

Q; 13 People think that beggary is a curse /sin as a Muslim

Q: 14 bagging is customary practices of Multan based baggers.

Q: 15 Do you feel disable face marriage related problems in Pakistan especially in Multan

Q: 16 In Multan (disable Husband/ wife) have rights to beat each other or any other condition of expression

Q: 17 bagging is necessary for both male and female disable of it's a sin

Q: 18 do you feel bagging is the sign of bravery for disable and public appreciate you for begging

Q: 19 Is disable female enjoying (providing/getting) the property rights

Q: 20 Do you think disable are compelled by their parents/family to transfer their property to their brother and bagging

Q: 21: Do you think Healthy bagger / professional bagger deprive the disable bagger rights in bagging

Q: 22 is disable equally treated in respect of health treatment by the family and governments / private places

Q: 23 Is disable /male / women's goes for registering FIR about any crime.

Q: 24 Any other problem that you can easily share with me

Thank you I will remain thankful for ever, for any other suggestion feel free to call me /email me. 